\title{
Rai1 Haploinsufficiency Is Associated with Social Abnormalities in Mice
}

\author{
Nalini R. Rao ${ }^{1}$, Clemer Abad ${ }^{1}$, Irene C. Perez ${ }^{1}$, Anand K. Srivastava ${ }^{2}$, Juan I. Young ${ }^{1,3}$ \\ and Katherina Walz 1,3,* \\ 1 John P. Hussman Institute for Human Genomics, University of Miami, Miami, FL 33136, USA; \\ nalini.rao326@gmail.com (N.R.R.); cabad@med.miami.edu (C.A.); irene.perez28@gmail.com (I.C.P.); \\ jyoung3@med.miami.edu (J.I.Y.) \\ 2 J.C. Self Research Institute, Greenwood Genetic Center, Greenwood, SC 29646, USA; anand@ggc.org \\ 3 Dr. John T. Macdonald Foundation Department of Human Genetics, Miller School of Medicine, \\ University of Miami, Miami, FL 33136, USA \\ * Correspondence: kwalz@med.miami.edu; Tel.: +1-305-243-1116
}

Academic Editor: Chris O'Callaghan

Received: 30 November 2016; Accepted: 20 April 2017; Published: 27 April 2017

\begin{abstract}
Background: Autism is characterized by difficulties in social interaction, communication, and repetitive behaviors; with different degrees of severity in each of the core areas. Haploinsufficiency and point mutations of RAI1 are associated with Smith-Magenis syndrome (SMS), a genetic condition that scores within the autism spectrum range for social responsiveness and communication, and is characterized by neurobehavioral abnormalities, intellectual disability, developmental delay, sleep disturbance, and self-injurious behaviors. Methods: To investigate the relationship between Rai1 and social impairment, we evaluated the $\mathrm{Rai1}^{+/-}$mice with a battery of tests to address social behavior in mice. Results: We found that the mutant mice showed diminished interest in social odors, abnormal submissive tendencies, and increased repetitive behaviors when compared to wild type littermates. Conclusions: These findings suggest that Rai1 contributes to social behavior in mice, and prompt it as a candidate gene for the social behaviors observed in Smith-Magenis Syndrome patients.
\end{abstract}

Keywords: Autism spectrum disorder; Smith-Magenis syndrome; Rai1; social behavior

\section{Introduction}

The difficulties and deficits observed in autism span a wide range as the disorder is characterized by various phenotypes. The spectrum of these phenotypes includes: difficulties in social interaction, verbal and nonverbal communication, and repetitive behaviors. Autism is recognized as an entity by itself, but autistic features are also present in several neurodevelopmental syndromes such as: Rett, Fragile-X, Angelman, Prader-Willi, Joubert, Tuberous sclerosis, and 22q13.3 deletion syndromes, among others [1]. One of those syndromes that includes autistic features is Smith-Magenis syndrome (SMS; Mendelian Inheritance in Man number (MIM), 182290).

SMS is a microdeletion syndrome with an estimated incidence of $1: 15,000$ to $1: 25,000$ live births [2,3]. The phenotypes more commonly associated with SMS are a variable degree of intellectual disability, speech and motor delay, behavior abnormalities with sleep disturbances, self-injurious and/or aggressive attention-seeking behavior, and distinctive craniofacial and skeletal anomalies [3]. SMS is typically caused by a deletion of chromosome $17 \mathrm{p} 11.2$ that encompasses multiple genes, including the retinoic acid-induced 1 (RAI1) gene or heterozygous mutation in the RAI1 gene [4-11].

SMS patients harboring the common full deletion have also been described to have stereotypies, sensory integration difficulties, and social communication problems consistent with select features of autism spectrum disorder (ASD) [12-16]. In a recent study, $90 \%$ of 26 individuals with SMS showed 
social responsiveness scale (SRS) scores consistent with ASD [13]. Moreover, the social responsiveness questionnaire scores consistently showed that a majority of individuals may meet the criteria of ASD at some point in their lifetime [13]. However, the likely contribution of the RAI1 gene to autistic features remains unknown.

Mice are very useful for understanding genotype-phenotype correlations. Studies in chromosomally engineered mice that carried a deletion of the SMS syntenic region in chromosome $11(D f(11) 17 /+)$ showed that these animals replicated most of the features observed in SMS patients, including abnormal social behaviors [17-19]. Mice carrying an inactivated Rai1 allele (Rai1 $\left.{ }^{+-}\right)$also recapitulate several SMS features but their social behavior was not yet investigated [19-22].

In order to understand the contribution of RAI1 to social behavior, we tested mice carrying an inactivated Rai1 allele $\left(\right.$ Rai1 $\left.^{+-}\right)$. The Rai1 ${ }^{+-}$mouse model showed diminished interest in social odors, abnormal submissive tendencies, and increased repetitive behaviors when compared to wild type littermates, strongly suggesting a role of RAI1 in social behaviors.

\section{Materials and Methods}

\subsection{Animals}

Heterozygous mice carrying an inactivated Rai1 allele were kindly donated by Dr. J.R. Lupski and backcrossed more than 12 times to wild type C57BL/6-Ty $r^{c-B r d}$. Mice were genotyped as previously described [22], and at the time of weaning, were housed in a cage with two to five animals of mixed genotypes. Housing conditions included a $12 \mathrm{~h}$ light: dark cycle (lights on at 6 AM, off at 6 PM) with access to food and water ad libitum. All animal testing was performed in accordance with the guidelines for the care and use of laboratory animals of the United States Public Health Service, National Institutes of Health, and was approved by The Institutional Animal Care and Use Committee at the University of Miami. The National Institutes of Health (NIH) Office of Laboratory Animal Welfare Assurance number is A3224-01. Behavioral testing of male mice began at 8 weeks of age, and all testing was performed between 9 AM-1 PM. The number of mice analyzed for all tests was Rai1 ${ }^{+/-}$ $=13$ and wild type $=12$ unless otherwise specified. Prior to each test, a habituation period of $30 \mathrm{~min}$ was given to the testing environment. The testing battery lasted five days and each day a single test was performed in the following order.

\subsection{General Health and Neurological Behavior}

Mice were evaluated for coat condition and whiskers. The visual placing reflex was carried out by elevating the mouse and then placing it on a bench. If the mouse placed both feet on the bench, the reflex was considered normal. Vibrissae orienting was performed as previously reported [23]. Throughout this evaluation, the vocalization of the mouse was recorded.

\subsection{Self-Grooming in A Novel Environment}

Each mouse was placed in a new cage without bedding for a habituation period of $10 \mathrm{~min}$. Following habituation, an observer with a stopwatch recorded the amount of time the mouse spent self-grooming out of a total time of $10 \mathrm{~min}$.

\subsection{Sociability and Social Preference}

We tested for sociability and social novelty using a rectangular three-chamber apparatus composed of clear carbonate [24]. This equipment contained free access to every chamber. The test consisted of three $10 \mathrm{~min}$ sessions, and was performed as previously described [23]. Briefly, in the first $10 \mathrm{~min}$ session, the mice were allowed to freely explore the three-chamber equipment. In the second $10 \mathrm{~min}$ session, an empty container was placed in the center of one chamber while an unfamiliar stranger mouse (stranger 1) was placed under a container on the other side of the chamber. The test mouse was located in the center chamber and allowed free access to the three chambers. The stranger 1 and 
the empty container were alternatively changed between chamber sides. Finally, in the third $10 \mathrm{~min}$ session, a new unfamiliar stranger mouse (stranger 2 ) was placed under the formerly empty container. The test mouse was placed in the center chamber with access to each chamber. For each of the three 10 min sessions, the total time spent in each was recorded. To exclude any environmental interference during the testing, the stranger 1 and the empty cage (during the sociability part of the test, or the stranger 1 and stranger 2, during the preference for social novelty test) were placed alternatively in the left or right side of the test chamber, and no significant difference in time spent within any of the chambers for any genotype was observed [25] $(p>0.05)$.

\subsection{Interest in Non-Social and Social Odors}

Each mouse was placed in a new cage with bedding for a habituation period of $60 \mathrm{~min}$ in the testing environment. Following habituation, each mouse was presented first with a cotton swab embedded with water for training. Then two non-social odors and two social odors were presented to them three times at separate intervals of $2 \mathrm{~min}$, with $1 \mathrm{~min}$ in between. The non-social odors were almond and banana extract diluted 1:100 in water. The novel social odors were obtained from two male mice of the same strain that were housed in a separate cage for more than two days. A cotton swab was immersed in each non-social odor and then placed $4-5 \mathrm{~cm}$ from the bottom of the cage. For the social odor, a cotton swab was swiped in a zigzag pattern across the bottom of each dirty cage that housed the unfamiliar mouse. The experiment was video-recorded and the amount of time the mouse sniffed within $3 \mathrm{~cm}$ of the cotton swab was documented.

\subsection{Dominance Tube Test}

Mice were trained to enter a clear acrylic tube from both sides and exit towards their respective opposite sides. The training time for each mouse was recorded. After training, two mice, both unfamiliar with each other, were allowed to enter the tube at the same time at opposite sides. An observer recorded the time it took for one mouse to cause the other to back out of the tube. The mouse that did not back out was classified as the winner. This was repeated again in round 2, changing the side of entry into the tube for each mouse [23].

\subsection{Statistical Tests}

Statistical analysis of weight, self-grooming time, and smelling time was performed utilizing the two-tailed Student's t-test and a $p$-value $\leq 0.05$ was considered significant. The dominance test was analyzed with the $X^{2}$ statistical test. Two-way (genotype $X$ side) ANOVA (Analysis of variance) with repeated measure (side) followed by a $t$-test analysis when a significant $F$-value was determined was utilized to analyze the sociability and social novelty preference data.

\section{Results}

\subsection{Abnormal Social Behaviors in Rai1 ${ }^{+/-}$Mice}

The clinical presentation between SMS patients harboring a common genomic deletion of $\sim 3 \mathrm{Mb}$ and patients with a point mutation in RAI1 is very alike. Despite the high incidence of autism in the group of patients harboring the common deletion $(\sim 90 \%)$ the incidence of autism in the group of patients carrying a Rai1 point mutation is still unknown (Table 1). On the other hand, $D f(11) 17^{+/-}$and $\mathrm{Rail}^{+/-}$mice were extensively studied and they both recapitulate SMS features very similarly (Table 2), making the Rai1 ${ }^{+-}$mouse a good model to study the contribution of RAI1 to the SMS phenotype. To understand the relationship between Rai1 and social behaviors, we examine the social responses of Rai $^{+/-}$mice. We utilized a set of specific tests that have been validated in mouse models and are relevant to human autistic behaviors [26]. We first tested our mice for general health and neurological reflexes, such as coat condition, piloerection, presence of full whiskers, visual placing reflex, and the 
vocalization during handling. No significant differences were found between the $\mathrm{Rai}^{+/-}$mice and their wild type littermates for any of these parameters [25].

Table 1. Comparison of the clinical presentation of SMS patients with common deletion and RAI1 mutations.

\begin{tabular}{|c|c|c|}
\hline \multirow[b]{2}{*}{ Phenotypes } & \multicolumn{2}{|c|}{ SMS Patients } \\
\hline & $\begin{array}{l}\text { \% in Common 17p11.2 } \\
\text { Deletion }[3,8,11]\end{array}$ & $\%$ in $R A I 1$ Mutations $[5,8,9,11]$ \\
\hline Craniofacial Abnormalities & 100 & 100 \\
\hline \multicolumn{3}{|l|}{ Skeletal Abnormalities } \\
\hline Short stature & $70-80$ & 11 \\
\hline Scoliosis/Vertebral Abnormalities & 73 & $40-50$ \\
\hline Short broad hands/Brachydactyly & 85 & 88 \\
\hline \multicolumn{3}{|l|}{ Otorhinolaryngological } \\
\hline Hoarse Voice & $66-80$ & $76-86$ \\
\hline Hearing loss & $60-68$ & $11-33$ \\
\hline \multicolumn{3}{|l|}{ Neurological } \\
\hline Cognitive Impairment & 100 & 100 \\
\hline Infantile hypotonia & $<90$ & $50-61$ \\
\hline Speech delay & $>90$ & 70 \\
\hline Motor delay & $>90$ & $60-70$ \\
\hline Sleep disturbance & 90 & 100 \\
\hline EEG abnormalities & $50-66$ & 80 \\
\hline Seizures & $11-30$ & $16.6-50$ \\
\hline \multicolumn{3}{|l|}{ Behavioral } \\
\hline Self-hugging & $50-80$ & 100 \\
\hline Onychotillomania & $25-85$ & $80-100$ \\
\hline Polyembolokoilamania & $25-85$ & $75-80$ \\
\hline Head banging/face slapping & 70 & 90 \\
\hline Hand biting & 80 & $60-71$ \\
\hline Attention seeking & 80-100 & 100 \\
\hline Aggressive behavior & & 55 \\
\hline Self-injurious behavior & $70-90$ & $>90$ \\
\hline Hyperactivity & 80 & 100 \\
\hline Autistic features & $90[7]$ & NR \\
\hline \multicolumn{3}{|l|}{ Other features } \\
\hline Cardiac defects & 30 & 0 \\
\hline Renal/urinary tract defect & 30 & 0 \\
\hline Obesity & 18 & 78 \\
\hline Overeating & 25 & 81 \\
\hline
\end{tabular}


Table 2. Comparison of neurological phenotypes in mice with the syntenic common 17p11.2 deletion and those with a Rai1 mutation.

\begin{tabular}{|c|c|c|}
\hline \multirow[b]{2}{*}{ Phenotypes } & \multicolumn{2}{|c|}{ SMS Mouse Models } \\
\hline & Common Deletion $[17,18,27]$ & $\operatorname{Rai1}^{+/-}[19,22]$ \\
\hline \multicolumn{3}{|l|}{ Neurological } \\
\hline Overt seizures & Yes $(\sim 20 \%)$ & Subtle \\
\hline EEG & Abnormal & Abnormal \\
\hline Locomotor activity $^{+}$ & Decreased & Decreased \\
\hline Anxiety $^{+}$ & Normal & Normal \\
\hline Learning and memory & Normal & Normal \\
\hline Social novelty recognition \& & Abnormal & Normal * \\
\hline Social (dominant behavior) ${ }^{\#}$ & Decreased & Decreased * \\
\hline Repetitive behaviors ${ }^{++}$ & NR & Increased * \\
\hline
\end{tabular}

A comparison of phenotypes patients with the common 17p11.2 deletion and those with intragenic mutations within RAI1 is shown. The percentages of occurrence for each of the phenotypes are given. $\mathrm{NR}=$ phenotype not reported.

We tested the sociability of $\mathrm{Rail}^{+/-}$and wild type mice as well as their preference for social novelty, utilizing the three-chamber test, which is based on measuring the place preference (in time spent) for the mice that reflects the innate propensity of a mouse to spend more time in proximity to another animal instead of an inanimate object $[23,24]$. The percentage of time spent for each genotype in each compartment during the habituation period was analyzed to check for any environmental interference within the social test chamber. No chamber preference was apparent for any genotype $(p>0.05)$.

The analysis of the sociability data showed no significant interaction between the genotype $X$ side $\left(F_{(1,59)}=1.94, p=0.17\right)$. No significant effect on genotype was found $\left(F_{(1,59)}=13.1, p=0.0006\right)$, but a main effect of chamber side $\left(F_{(1,59)}=0.12, p=0.73\right)$ is present (Figure 1A) indicating that both genotypes are equally sociable.

The second part of the test was done to evaluate the preference for social novelty of the different genotypes. We analyzed the preference for social novelty data and observed no significant effect of genotype $\left(F_{(1,59)}=0.1, p=0.75\right)$ nor interaction genotype $\mathrm{X}$ side $\left(F_{(1,59)}=0.96, p=0.33\right)$. A significant main effect for side $\left(F_{(1,28)}=8.77, p=0.0045\right)$, was present, suggesting no difference on the preference for social novelty between mutant and wildtype mice (Figure 1B).

Olfactory clues are essential to mouse communication. In addition, a measure of social interest can be obtained by examining the amount of time spent by a mouse smelling non-social and social odors. Here we compared the interest in non-social or social odors between both genotypes by presenting mice with two non-social odors: almond (NS-1) and banana (NS-2), and two different social odors (S-1, S-2). The time spent from the first two trials of each respective odor was averaged and a two-tailed Student's t-test was performed to analyze the data. There was no significant difference in the time spent interested in non-social odors between both genotypes, for NS-1 $(p=0.96)$ and for NS-2 $(p=0.21)$ (Figure 1C). However, when the mice were exposed to social odors we found that $\mathrm{Rai1}^{+/-}$mice spent significantly less time smelling the social odors compared to their wild type littermates (S- $1 p<0.001$, S-2 $p<0.001$ ). This reinforces the idea of an abnormal social response for the mutant mice (Figure 1D). 
A
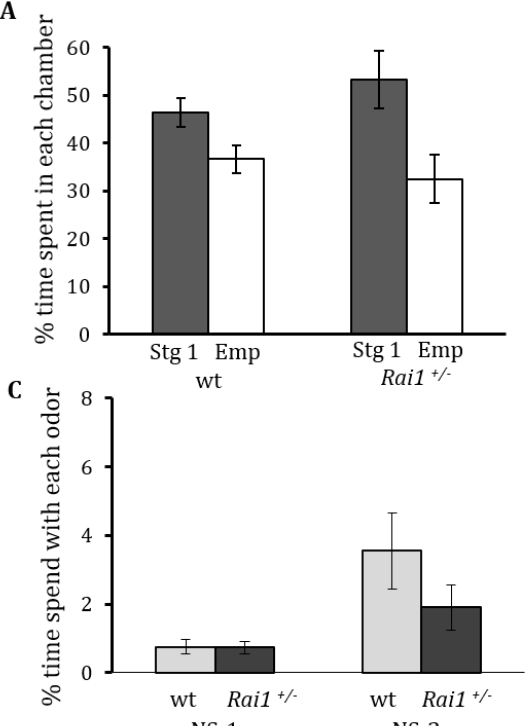
NS-1 NS-2

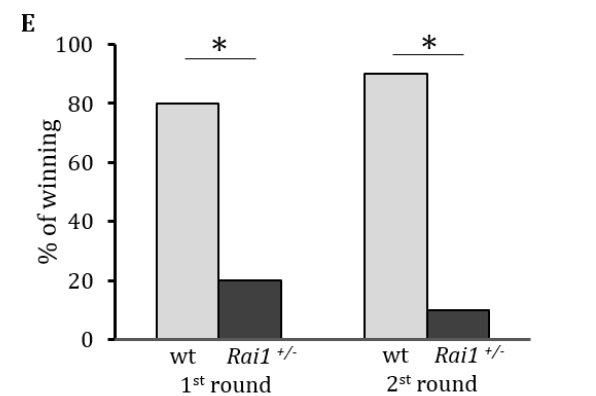

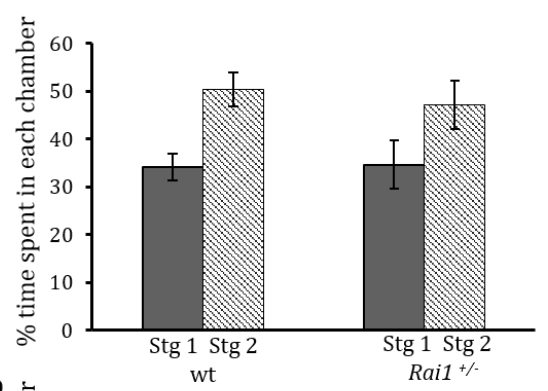
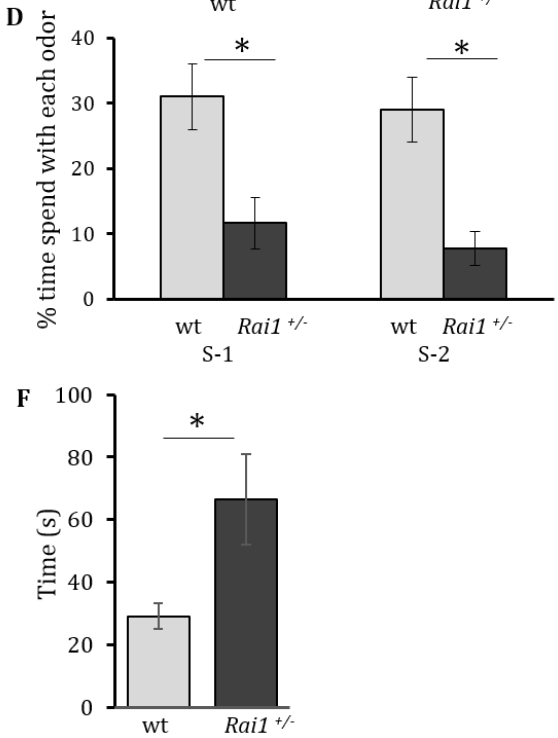

Figure 1. Evaluation of social behaviors in $\mathrm{Rai1}^{+-}$mice. (A) Sociability in $\mathrm{Rai1}^{+/-}$mice is shown. Percentages of time spent in the chamber side with stranger 1 (Stg1, black column) or with the empty container (Emp, white column) during the sociability test are shown for the wild type and Rai1 ${ }^{+/-}$ mice. (B) Social novelty preference was evaluated. Percentages of time spent in the chamber side with stranger 1 (Stg1, black column) or with stranger 2 (Stg 2, striped column) during the preference for social novelty test are depicted. (C) The amount of time spent smelling non-social (NS) odors for both genotypes is shown. NS1 = Almond, NS2 = banana. (D) The amount of time spent smelling social (S) odors for both genotypes is shown. (E) Tube test. The results for the first and second round are depicted as the percentage of winning for each genotype. Wild type mice (grey column) and $\mathrm{Rail}^{+/-}$ mice (black column) are represented. (F) Total time spent self-grooming for each genotype is shown. Wild type animals are represented in the grey column and Rai1 $^{+/-}$mice in the black column. Asterisk denotes significant difference $\left({ }^{*} p<0.05\right)$. The mean \pm SEM values are depicted.

To further evaluate social interactions we used the tube test, a paradigm previously found to be useful in predicting social behavior abnormalities [23,28]. When confronted by another mouse coming from the opposite end of a tube in which they cannot turn around, wild type mice explore each other for a short while and then randomly push the opposing mice, or retreat the tube by walking backwards. However, as can be seen in Figure 1E, when Rai1 ${ }^{+/-}$mice confronted wild type mice, they backed out of the tube more times than expected by chance ( $80 \%$ of the time) compared with the wild type mice (20\% of the time). This test was repeated with the same pair of mice for a second round, switching the side from which each mouse starts. As can be seen in Figure 1E, Rai1 ${ }^{+-}$mice again backed out significantly more than expected ( $90 \%$ of the time), compared with the wild type mice (10\% of the time) eliminating the possibility of tube side bias. As each $\mathrm{Rai1}^{+/-}$mouse required a wild type opponent, $\mathrm{n}=12$ was used for $\mathrm{Rai1}^{+/-}$and wild type groups. These results of the chi-squared test performed showed that they were significantly different $\left(X^{2}, p<0.001\right)$. 
No aggressive behaviors during the encounters were observed. No differences were found between Rail $^{+/-}$and wild type mice in the time they took to walk out of the tube during training. In addition to this, no difference was found in strength or in weight between the groups, suggesting increased anxiety in a novel arena when faced with a non-familiar mouse.

\subsection{Repetitive Behaviors Were Augmented in Rai1 ${ }^{+/-}$Mice}

Repetitive behaviors in this study were evaluated by measuring the time spent self-grooming in a novel environment during a $10 \mathrm{~min}$ period. A significant increase in self-grooming time was found for Rai1 ${ }^{+/-}(66.6+/-14 \mathrm{~s})$ animals compared to their wild type littermates $(29+/-4.5 \mathrm{~s})(p<0.03)$ (Figure 1F), suggesting an increase of repetitive behaviors in the mutant mice.

\section{Discussion}

SMS is a neurodevelopmental disorder with a clinical presentation that includes craniofacial dysmorphic features, abnormal circadian rhythm, and cognitive impairment with behavioral and psychiatric symptoms. In addition, individuals with SMS have also been described to have stereotypies, sensory integration difficulties, and social communication problems consistent with select features of ASD [13]. Several heterozygous RAI1 gene mutations have been found to be associated with SMS. These mutations include nonsense, missense, and frameshift mutations caused by deletions of one or multiple nucleotides [5-11]. In addition, the RAI1 gene has also been associated with spinocerebellar ataxia (SCA2), schizophrenia, and autism [29-31].

We have previously developed and described a mouse model for SMS, $D f(11) 17^{+/}$mice, carrying a genomic deletion of $\sim 23$ genes in the mouse genomic region syntenic to the human deleted region [17]. This mouse model recapitulates several physical and behavioral aspects present in SMS, including social behavior abnormalities $[18,19]$. Here we explore the role of Rai1 in the social phenotype of the mice. We show that haploinsufficiency of the Rai1 gene is enough to cause some abnormal social behaviors in mice (Table 2) utilizing very standardized tests that were previously reported to study autistic like behaviors in mice [26].

Social interaction in mice is heavily based on the reliance of olfactory cues. In the olfactory test there was no significance difference between wild type and Rai1 ${ }^{+/-}$mice in the time spent smelling non-social cues, indicating that olfactory function in mutant mice is normal. However, Rai ${ }^{+/-}$mice showed a lack of interest in social odors when compared to wild type littermates suggesting an impaired discrimination of social olfactory cues. This same phenotype was observed in mutants for Tsc1 [32], a mouse model for Tuberous Sclerosis syndrome, a genetic disorder with high rates of comorbid ASDs.

The grooming test is utilized to investigate repetitive behaviors in mice. Rai1 ${ }^{+/-}$mice showed increase repetitive behaviors in the grooming test when compared with their wild type littermates, suggesting an increase of stereotypic behaviors. Significantly more self-grooming time was also found in other mouse models as mutants for Shank2 [33], Tsc1 [32], Neurexin 1 $\alpha$ [34], En2 [35], and Ankrd11 [36], all candidates for autistic like behaviors.

The tube test is used as a measure for social dominance. The results showed that the Rai1 ${ }^{+/-}$ mice displayed abnormal submissive tendencies, in concordance to the phenotype previously seen for $D f(11) 17^{+/-}$mice in this same test [19]. Again this phenotype was observed in different mouse models for autistic candidate genes as mutants for Fmr1 [37].

To test for sociability and preference to social novelty we utilized the three-chamber test. No significant difference was found between wild type and Rai1 mutant mice. Recently, a new mouse model of Rai1 deficiency was developed where Rai1 ablation was done conditionally in different neuronal populations [38]. In this mouse model the three chamber test result was similarly not significant. Interestingly enough, some other mouse models of autism were negative in the three chamber test as Nlgn3 knock-in mouse [39] and Fmr1 [40]. The behaviors measured in the three-chamber test may not be correlated to reciprocal social interaction in a naturalistic environment, 
therefore these two groups of mice may behave differently in a home cage behavior analysis [37,41,42]. Also, it may not be clear if the approach toward a caged mouse reflects an affiliative social approach or aggressive behavior, but during observation of our three-chamber test, it is more likely that the approach toward the stranger mouse reflects affiliative social behavior as the subjects did not demonstrate any aggressive behavior phenotypes such as: tail rattling, chasing, or aggressive attacks [43]. It should also be noted that mice by nature are territorial and the design of this experiment does not allow for direct interaction in this apparatus therefore we are unable to state if this behavior is reflective of ASD-related behavior.

A more suitable behavioral test to investigate social interactions in addition to the three-chamber test would be a home-cage social interaction test and a novel environment social interaction test [44]. While we are unable to state if this test is reflective of ASD-related behavior, the results of the three-chamber test suggest that the wild type and Rai1 mutant animals behave in the same manner in this behavior test.

We have shown here that Rai1 haploinsufficiency is enough to cause several social abnormalities in mice. These results parallel those previously seen with various other mouse models for social behavior abnormalities, as summarized in Silverman et al, 2010 [26]. Most Rai1 ${ }^{-/}$mice died during embryonic development [22], however, it was possible to show that Rai1 ${ }^{-1-}$ mice that survive present a more severe phenotype than Rai $^{+/-}$mice, including the learning disability, motor deficiency, and seizures [21]. It would be interesting to see the effect of Rail knock out on social behavior.

In summary, our data shows that Rai1 is responsible for social abnormalities in mice, and reinforces the idea that Rai1 should be considered a candidate gene in children with autistic manifestations or social abnormalities.

\section{Conclusions}

Our data shows that Rai1 is responsible for social abnormalities in mice, and reinforces the idea that Rai1 should be considered as a candidate gene in children with autistic manifestations or social abnormalities.

Acknowledgments: We thank Erna Stoddart for administrative support and English proofreading of this article and J. Sunil Rao for the overview of the statistical test of the three-chamber test. The mouse line was generously provided James R. Lupski. This project was supported in part by the Le Jerome Lejeune Foundation (to Katherina Walz).

Author Contributions: Katherina Walz conceptualized and drafted the manuscript and approved the final manuscript as submitted. Katherina Walz and Juan I. Young designed the study protocols and data collection procedures, reviewed and revised the manuscript, and approved the final manuscript as submitted. Nalini R. Rao, Clemer Abad and Irene C. Perez performed the experiments, data collection and analysis, reviewed and revised the manuscript, and approved the final manuscript as submitted. Anand K. Srivastava reviewed and revised the manuscript, and approved the final manuscript as submitted. All authors read and approved the final manuscript.

Conflicts of Interest: The authors declare no conflict of interest.

\section{References}

1. Casanova, E.L.; Sharp, J.L.; Chakraborty, H.; Sumi, N.S.; Casanova, M.F. Genes with high penetrance for syndromic and non-syndromic autism typically function within the nucleus and regulate gene expression. Mol. Autism 2016, 7. [CrossRef] [PubMed]

2. Greenberg, F.; Guzzetta, V.; Montes de Oca-Luna, R.; Magenis, R.E.; Smith, A.C.; Richter, S.F.; Kondo, I.; Dobyns, W.B.; Patel, P.I.; Lupski, J.R. Molecular analysis of the Smith-Magenis syndrome: A possible contiguous-gene syndrome associated with del(17)(p11.2). Am. J. Hum. Genet. 1991, 49, 1207-1218. [PubMed]

3. Edelman, E.A.; Girirajan, S.; Finucane, B.; Patel, P.I.; Lupski, J.R.; Smith, A.C.; Elsea, S.H. Gender, genotype, and phenotype differences in Smith-Magenis syndrome: A meta-analysis of 105 cases. Clin. Genet. 2007, 71, 540-550. [CrossRef] [PubMed]

4. Slager, R.E.; Newton, T.L.; Vlangos, C.N.; Finucane, B.; Elsea, S.H. Mutations in RAI1 associated with Smith-Magenis syndrome. Nat. Genet. 2003, 33, 466-468. [CrossRef] [PubMed] 
5. Bi, W.; Saifi, G.M.; Shaw, C.J.; Walz, K.; Fonseca, P.; Wilson, M.; Potocki, L.; Lupski, J.R. Mutations of RAI1, a PHD-containing protein, in nondeletion patients with Smith-Magenis syndrome. Hum. Genet. 2004, 115, 515-524. [CrossRef] [PubMed]

6. Girirajan, S.; Elsas, L.J.; Devriendt, K.; Elsea, S.H. RAI1 variations in Smith-Magenis syndrome patients without 17p11.2 deletions. J. Med. Genet. 2005, 42, 820-828. [CrossRef] [PubMed]

7. Bi, W.; Saifi, G.M.; Girirajan, S.; Shi, X.; Szomju, B.; Firth, H.; Magenis, R.E.; Potocki, L.; Elsea, S.H.; Lupski, J.R. RAI1 point mutations, CAG repeat variation, and SNP analysis in non-deletion Smith-Magenis syndrome. Am. J. Med. Genet. A 2006, 140, 2454-2463. [CrossRef] [PubMed]

8. Girirajan, S.; Vlangos, C.N.; Szomju, B.B.; Edelman, E.; Trevors, C.D.; Dupuis, L.; Nezarati, M.; Bunyan, D.J.; Elsea, S.H. Genotype-phenotype correlation in Smith-Magenis syndrome: Evidence that multiple genes in 17p11.2 contribute to the clinical spectrum. Genet. Med. 2006, 8, 417-427. [CrossRef] [PubMed]

9. Truong, H.T.; Dudding, T.; Blanchard, C.L.; Elsea, S.H. Frameshift mutation hotspot identified in Smith-Magenis syndrome: Case report and review of literature. BMC Med. Genet. 2010, 11. [CrossRef] [PubMed]

10. Vilboux, T.; Ciccone, C.; Blancato, J.K.; Cox, G.F.; Deshpande, C.; Introne, W.J.; Gahl, W.A.; Smith, A.C.; Huizing, M. Molecular analysis of the retinoic acid induced 1 gene (RAI1) in patients with suspected Smith-Magenis syndrome without the 17p11.2 deletion. PLoS ONE 2011, 6, e22861. [CrossRef] [PubMed]

11. Vieira, G.H.; Rodriguez, J.D.; Carmona-Mora, P.; Cao, L.; Gamba, B.F.; Carvalho, D.R.; De Rezende Duarte, A.; Santos, S.R.; De Souza, D.H.; DuPont, B.R.; et al. Detection of classical 17p11.2 deletions, an atypical deletion and RAI1 alterations in patients with features suggestive of Smith-Magenis syndrome. Eur. J. Hum. Genet. 2012, 20, 148-154. [CrossRef] [PubMed]

12. Gropman, A.L.; Duncan, W.C.; Smith, A.C. Neurologic and developmental features of the Smith-Magenis syndrome (del 17p11.2). Pediatr. Neurol. 2006, 34, 337-350. [CrossRef] [PubMed]

13. Laje, G.; Morse, R.; Richter, W.; Ball, J.; Pao, M.; Smith, A.C. Autism spectrum features in Smith-Magenis syndrome. Am. J. Med. Genet. C Semin. Med. Genet. 2010, 154C, 456-462. [CrossRef] [PubMed]

14. Wolters, P.L.; Gropman, A.L.; Martin, S.C.; Smith, M.R.; Hildenbrand, H.L.; Brewer, C.C.; Smith, A.C. Neurodevelopment of children under 3 years of age with Smith-Magenis syndrome. Pediatr. Neurol. 2009, 41, 250-258. [CrossRef] [PubMed]

15. Wilde, L.; Silva, D.; Oliver, C. The nature of social preference and interactions in Smith-Magenis syndrome. Res. Dev. Disabil. 2013, 34, 4355-4365. [CrossRef] [PubMed]

16. Osorio, A.; Sampaio, A.; Martínez Regueiro, R.; Garayzábal Heinze, E.; Carracedo, A.; Fernández Prieto, M. Autism spectrum symptoms in Smith-Magenis syndrome and Williams syndrome: Comparisons and contrasts. Int. J. Dev. Disabil. 2015, 61, 49-55. [CrossRef]

17. Walz, K.; Caratini-Rivera, S.; Bi, W.; Fonseca, P.; Mansouri, D.L.; Lynch, J.; Vogel, H.; Noebels, J.L.; Bradley, A.; Lupski, J.R. Modeling del(17)(p11.2p11.2) and dup(17)(p11.2p11.2) contiguous gene syndromes by chromosome engineering in mice: Phenotypic consequences of gene dosage imbalance. Mol. Cell. Biol. 2003, 23, 3646-3655. [CrossRef] [PubMed]

18. Walz, K.; Spencer, C.; Kaasik, K.; Lee, C.C.; Lupski, J.R.; Paylor, R. Behavioral characterization of mouse models for Smith-Magenis syndrome and dup(17)(p11.2p11.2). Hum. Mol. Genet. 2004, 13, 367-378. [CrossRef] [PubMed]

19. Ricard, G.; Molina, J.; Chrast, J.; Gu, W.; Gheldof, N.; Pradervand, S.; Schutz, F.; Young, J.I.; Lupski, J.R.; Reymond, A.; et al. Phenotypic consequences of copy number variation: Insights from Smith-Magenis and Potocki-Lupski syndrome mouse models. PLoS Biol. 2010, 8, e1000543. [CrossRef] [PubMed]

20. Walz, K.; Paylor, R.; Yan, J.; Bi, W.; Lupski, J.R. Rai1 duplication causes physical and behavioral phenotypes in a mouse model of dup(17)(p11.2p11.2). J. Clin. Invest. 2006, 116, 3035-3041. [CrossRef] [PubMed]

21. Bi, W.; Yan, J.; Shi, X.; Yuva-Paylor, L.A.; Antalffy, B.A.; Goldman, A.; Yoo, J.W.; Noebels, J.L.; Armstrong, D.L.; Paylor, R.; et al. Rail deficiency in mice causes learning impairment and motor dysfunction, whereas Rai1 heterozygous mice display minimal behavioral phenotypes. Hum. Mol. Genet. 2007, 16, 1802-1813. [CrossRef] [PubMed]

22. Bi, W.; Ohyama, T.; Nakamura, H.; Yan, J.; Visvanathan, J.; Justice, M.J.; Lupski, J.R. Inactivation of Rai1 in mice recapitulates phenotypes observed in chromosome engineered mouse models for Smith-Magenis syndrome. Hum. Mol. Genet. 2005, 14, 983-995. [CrossRef] [PubMed] 
23. Molina, J.; Carmona-Mora, P.; Chrast, J.; Krall, P.M.; Canales, C.P.; Lupski, J.R.; Reymond, A.; Walz, K. Abnormal social behaviors and altered gene expression rates in a mouse model for Potocki-Lupski syndrome. Hum. Mol. Genet. 2008, 17, 2486-2495. [CrossRef] [PubMed]

24. Nadler, J.J.; Moy, S.S.; Dold, G.; Trang, D.; Simmons, N.; Perez, A.; Young, N.B.; Barbaro, R.P.; Piven, J.; Magnuson, T.R.; et al. Automated apparatus for quantitation of social approach behaviors in mice. Genes Brain Behav. 2004, 3, 303-314. [CrossRef] [PubMed]

25. Rao, N.R.; Abad, C.; Perez, I.C.; Young, J.I.; Walz, K.; John, P.; Hussman Institute for Human Genomics. University of Miami: Miami, FL, USA, 2016; Unpublished data.

26. Silverman, J.L.; Yang, M.; Lord, C.; Crawley, J.N. Behavioural phenotyping assays for mouse models of autism. Nat. Rev. Neurosci. 2010, 11, 490-502. [CrossRef] [PubMed]

27. Goldman, A.M.; Potocki, L.; Walz, K.; Lynch, J.K.; Glaze, D.G.; Lupski, J.R.; Noebels, J.L. Epilepsy and chromosomal rearrangements in Smith-Magenis Syndrome [del(17)(p11.2p11.2)]. J. Child Neurol. 2006, 21, 93-98. [CrossRef] [PubMed]

28. Shahbazian, M.; Young, J.; Yuva-Paylor, L.; Spencer, C.; Antalffy, B.; Noebels, J.; Armstrong, D.; Paylor, R.; Zoghbi, H. Mice with truncated MeCP2 recapitulate many Rett syndrome features and display hyperacetylation of histone H3. Neuron 2002, 35, 243-254. [CrossRef]

29. Hayes, S.; Turecki, G.; Brisebois, K.; Lopes-Cendes, I.; Gaspar, C.; Riess, O.; Ranum, L.P.; Pulst, S.M.; Rouleau, G.A. CAG repeat length in RAI1 is associated with age at onset variability in spinocerebellar ataxia type 2 (SCA2). Hum. Mol. Genet. 2000, 9, 1753-1758. [CrossRef] [PubMed]

30. Joober, R.; Benkelfat, C.; Toulouse, A.; Lafreniere, R.G.; Lal, S.; Ajroud, S.; Turecki, G.; Bloom, D.; Labelle, A.; Lalonde, P.; et al. Analysis of 14 CAG repeat-containing genes in schizophrenia. Am. J. Med. Genet. 1999, 88, 694-699. [CrossRef]

31. Van der Zwaag, B.; Franke, L.; Poot, M.; Hochstenbach, R.; Spierenburg, H.A.; Vorstman, J.A.; Van Daalen, E.; De Jonge, M.V.; Verbeek, N.E.; Brilstra, E.H.; et al. Gene-network analysis identifies susceptibility genes related to glycobiology in autism. PLoS ONE 2009, 4, e5324. [CrossRef] [PubMed]

32. Tsai, P.T.; Hull, C.; Chu, Y.; Greene-Colozzi, E.; Sadowski, A.R.; Leech, J.M.; Steinberg, J.; Crawley, J.N.; Regehr, W.G.; Sahin, M. Autistic-like behavior and cerebellar dysfunction in Purkinje cell Tsc1 mutant mice. Nature 2012, 488, 647-651. [CrossRef] [PubMed]

33. Won, H.; Lee, H.; Gee, H.Y.; Mah, W.; Kim, J.; Lee, J.; Ha, S.; Chung, C.; Jung, E.S.; Park, S.; et al. Autistic-like behavior in Shank2-mutant mice improved by restoring NMDA receptor function. Nature 2014, 486, 261-265. [CrossRef] [PubMed]

34. Etherton, M.R.; Blaiss, C.A.; Powell, C.M.; Sudhof, T.C. Mouse neurexin-1 $\alpha$ deletion causes correlated electrophysiological and behavioral changes consistent with cognitive impairments. Proc. Natl. Acad. Sci. USA 2009, 106, 17998-18003. [CrossRef] [PubMed]

35. Cheh, M.A.; Millonig, J.H.; Roselli, L.M.; Ming, X.; Jacobsen, E.; Kamdar, S.; Wagner, G.C. En2 knockout mice display neurobehavioral and neurochemical alterations relevant to autism spectrum disorder. Brain Res. 2006, 1116, 166-176. [CrossRef] [PubMed]

36. Gallagher, D.; Voronova, A.; Zander, M.A.; Cancino, G.I.; Bramall, A.; Krause, M.P.; Abad, C.; Tekin, M.; Neilsen, P.M.; Callen, D.F.; et al. Ankrd11 is a chromatin regulator involved in autism that is essential for neural development. Dev. Cell. 2015, 32, 31-42. [CrossRef] [PubMed]

37. Spencer, C.M.; Alekseyenko, O.; Serysheva, E.; Yuva-Paylor, L.A.; Paylor, R. Altered anxiety-related and social behaviors in the Fmr1 knockout mouse model of fragile X syndrome. Genes Brain Behav. 2005, 4, 420-430. [CrossRef] [PubMed]

38. Huang, W.; Guenthner, C.J.; Xu, J.; Nguyen, T.; Schwarz, L.A.; Wilkinson, A.W.; Gozani, O.; Chang, H.Y.; Shamloo, M.; Luo, L. Molecular and neural functions of Rai1, the casual gene for smith-magenis syndrome. Neuron 2016, 92, 392-406. [CrossRef] [PubMed]

39. Chadman, K.K.; Gong, S.; Scattoni, M.L.; Boltuck, S.E.; Gandhy, S.U.; Heintz, N.; Crawley, J.N. Minimal aberrant behavioral phenotypes of neuroligin-3 R451C knockin mice. Autism Res. 2008, 1, 147-158. [CrossRef] [PubMed]

40. McNaughton, C.H.; Moon, J.; Strawderman, M.S.; Maclean, K.N.; Evans, J.; Strupp, B.J. Evidence for social anxiety and impaired social cognition in a mouse model of fragile $X$ syndrome. Behav. Neurosci. 2008, 122, 293-300. [CrossRef] [PubMed] 
41. Spencer, C.M.; Alekseyenko, O.; Hamilton, S.M.; Thomas, A.M.; Serysheva, E.; Yuva-Paylor, L.A.; Paylor, R. Modifying behavioral phenotypes in Fmr1 KO mice: Genetic background differences reveal autistic-like responses. Autism Res. 2011, 4, 40-56. [CrossRef] [PubMed]

42. Fairless, A.H.; Katz, J.M.; Vijayvargiya, N.; Dow, H.C.; Kreibich, A.S.; Berrettini, W.H.; Abel, T.; Brodkin, E.S. Development of home cage social behaviors in BALB/cJ vs C57BL/6J mice. Behav. Brain Res. 2013, 237, 338-347. [CrossRef] [PubMed]

43. Crawley, J.N.; Belknap, J.K.; Collins, A.; Crabbe, J.C.; Frankel, W.; Henderson, N.; Hitzemann, R.; Maxson, S.C.; Miner, L.L.; Silva, A.J.; et al. Behavioral phenotypes of inbred mouse strains: Implications and recommendations for molecular studies. Psychopharmacology 1997, 132, 107-124. [CrossRef] [PubMed]

44. Ohashi, R.; Takao, K.; Miyakawa, T.; Shiina, N. Comprehensive behavioral analysis of RNG105 (Caprin 1) heterozygous mice: Reduced social interaction and attenuated response to novelty. Sci. Rep. 2016, 6. [CrossRef]

(C) 2017 by the authors. Licensee MDPI, Basel, Switzerland. This article is an open access article distributed under the terms and conditions of the Creative Commons Attribution (CC BY) license (http:/ / creativecommons.org/licenses/by/4.0/). 